\title{
Keseragaman Dalam Galur dan Keragaman Antar Galur Mutan Padi Hasil Iradiasi Varietas Lokal Kalimantan Selatan
}

\section{Intra Lines Uniformity and Inter Lines Variation of Rice Mutants Resulting from Irradiation of South Kalimantan Local Varieties}

\author{
Raihani Wahdah, Gusti Rumayadi dan Rahmi Zulhidiani \\ Fakultas Pertanian Universitas Lambung Mangkurat Banjarbaru \\ Jalan A Yani Km 36 Banjarbaru, Kalimantan Selatan \\ Email : raihn pascagro@yahoo.com; gustirusmayadi@yahoo.co.id; \\ rahmizulhidiani@yahoo.co.id \\ Diterima 15-08-2016; Diterima dengan revisi 13-09-2016; Disetujui 12-10-2016
}

\begin{abstract}
ABSTRAK
Preferensi petani lahan rawa terhadap padi varietas lokal cukup tinggi, namun varietas lokal memiliki karakter umur panjang dan hasil rendah, sehingga perlu dilakukan perbaikan untuk sifat tersebut. Penelitian ini merupakan bagian kegiatan perbaikan padi varietas lokal untuk menghasilkan galur-galur harapan berumur pendek-sedang, namun tetap mempertahankan bentuk gabah yang ramping dan rasa nasi pera.Tujuan dari penelitian ini adalah untuk mengetahui keseragaman dalam galur dan keragaman antar galur mutan padi generasi M5. Penelitian dilaksanakan di Sawah Percobaan Fakultas Pertanian Universitas Lambung Mangkurat dari Maret - September 2014. Penelitian menggunakan 150 galur yang berbunga paling awal dari 300 galur mutan yang ditanam. Keseragaman dalam galur dianalisis dengan membandingkan ragam masing-masing galur mutan dengan ragam induknya. Keragaman antar galur dilakukan dengan membandingkan ragam semua galur dengan induknya. Lebih dari $85 \%$ galur mutan M5 asal induk Siam Harli dan $>79 \%$ asal induk Siam Kuatek sudah seragam. Karakter yang sudah seragam pada semua galur M5, baik asal induk Siam Harli maupun Siam Kuatek adalah umur panen, jumlah gabah isi, dan jumlah gabah hampa. Tidak ada keragaman antar galur mutan M5, tetapi sebagian galur induk asal Siam Harli maupun Siam Kuatekmemiliki beberapa karakter yang lebih baik daripada induknya, sehingga terbuka peluang untuk melakukan seleksi.
\end{abstract}

Kata Kunci : keseragaman, keragaman, galur mutan M5, padi varietas lokal Kalimantan Selatan

\begin{abstract}
The preference of farmer in tidal swampon local ricevarieties are quite high,but local varieties have a long life and low yield characters, so it needs to be improved for the trait.This study ispart of activities of the localrice varieties improvement to generate promising lineswere short-moderate aged,but the slimming and pera (high amilose content) grains maintained. The aims of this study were to determine the intralines uniformity and the inter lines variation of M5 generation of rice mutant lines. The experiment was carried out in the Experimental Station of Agriculture Faculty, Lambung Mangkurat University from March to September 2014. The experiment used 150 earliest flowering lines of 300 M5 mutant lines that were planted. Intralines uniformity were analysed by comparing the variance of each mutant lines with variance of its parent, while the variation among lineswere analyzed by comparing the variance of all lines with variance of its parent. More than $85 \%$ M5 mutant lines from Siam Harli as parent and $>79 \%$ of Siam Kuatek as parent are uniform. The uniform character at all M5 mutant lines, both of Siam Harli or Siam Kuatek parent are the harvest age, the filled grains number, and the empty grains number. There is no variability between M5 mutant lines, but some of M5 mutant lines from Siam Harli and Siam Kuatek have some better characters than their parents, so there is an opportunity for selection
\end{abstract}

Keywords : uniformity, variation, M5mutant line, South Kalimantan local rice varieties

\section{PENDAHULUAN}

Lahan rawa pasang surut semakin penting peranannya dalam upaya peningkatan produksi padi. Menurut Djaenudin [1], luas lahan rawa pasang surut mencapai 25,29 juta ha, yang meliputi Sumatera, Kalimantan, sebagian Sulawesi, dan Papua. Namun menurut Sudana [2] 
pemanfaatan lahan rawa pasang surut menghadapi beberapa keterbatasan, antara lain masalah tanah dan air.

Sebagian besar petani padi di lahan rawa pasang surut menanam varietas lokal. Preferensi petani terhadap varietas lokal tinggi, karena kemudahan budi daya, minim saprodi, harga jual tinggi, dan karakteristik beras/nasi yang disukai [3]. Pada tahun 2012 dilaporkan luas area pertanaman padi unggul adalah $54.98 \%$ sedangkan pertanaman lokal adalah $45.02 \%$ [4]. Salah satu kelemahan padi lokal adalah umur panjang dengan kisaran hasil 1,5 - 6,1 t/ha [5].

Varietas unggul dan bermutu yang adaptif merupakan salah satu sarana produksi yang penting dalam manajemen lahan basah guna mencapai potensi hasil yang dimiliki. Penelitian ini merupakan bagian dari kegiatan perbaikan varietas padi lokal untuk mengatasi perubahan iklim global dalam kaitannya dengan pemanfaatan periode tanam yang lebih pendek dengan cara menghasilkan galur-galur harapan berumur pendek-sedang, yaitu $<130$ hari setelah semai (induk mutan berumur $>160$ hari setelah semai). Di sisi lain karakteristik butir gabah yang ramping dan pera tetap dipertahankan.

Teknik mutasi mempunyai beberapa keuntungan dalam perbaikan karakter agronomi padi, yaitu: 1. Hampir semua karakter dapat diperbaiki melalui mutasi sepanjang karakter tersebut di alam juga beragam, 2. Dapat menginduksi mutasi alelik ataupun non alelik, 3 . Teknik mutasi berguna khususnya untuk perbaikan karakter agronomi padi lokal yang tidak dapat dilakukan melalui persilangan konvensional [6]. Beberapa penelitian yang menggunakan sinar gamma adalah pengaruh sinar gamma terhadap perubahan genetik manggis [7], memperbaiki tanaman padi $[6,9]$.

Hasil observasi tahun 2009 diperoleh sejumlah varietas padi lokal, yaitu 13 varietas di kecamatan Kurau, 11 varietas di Kecamatan Bumi Makmur, 26 varietas di Kecamatan Tabunganen, dan 12 varietas di Kecamatan Barambai [3]. Hingga tahun 2014 melalui seleksi pedigree mulai generasi mutan M2 telah dihasilkan galur mutan padi populasi generasi M5 yang berasal dari induk Siam Harli dan Siam Kuatek.

Perbaikan karakter melalui program pemuliaan tanaman membutuhkan banyak informasi antara lain tentang keragaman antar galur yang akan diseleksi yang berkontribusi penting pada keberhasilan seleksi. Keseragaman sifat (karakter) pada galur terseleksi merupakan karakteristik penting dalam seleksi. Sasmita [10] menyatakan bahwa keseragaman dalam galur merupakan penciri homozogisitas gen yang mengendalikan karakter tersebut.

Tujuan dari penelitian ini adalah untuk mengetahui keseragaman dalam galur dan keragaman antar galur mutan padi populasi generasi mutan M5 asal varietas lokal Kalimantan Selatan sebagai bahan seleksi untuk uji daya hasil pendahuluan dan uji daya hasil lanjutan.

\section{BAHAN DAN METODE}

\section{Lokasi penelitian}

Penelitian dilaksanakan di Sawah Percobaan Fakultas Pertanian Universitas Lambung Mangkurat, Desa Sungai Rangas Hambuku, Kecamatan Martapura Barat, Kabupaten Banjar, Provinsi Kalimantan Selatan dari Maret - September 2014.

\section{Bahan dan alat}

Induksi mutasi dilakukan pada benih padi di PAIR-BATAN (Pusat Aplikasi Isotop \& RadiasiBadan Tenaga Nuklir Nasional) Jakarta pada tahun 2010. Bahan penelitian adalah 300 galur generasi mutan M5 terdiri 95 galur asal induk Siam Harli dan 205 galur asal induk Siam Kuatek, bahan dan alat untuk budidaya padi, serta bahan dan alat untuk pengukuran variabel pengamatan.

\section{Pelaksanaan dan disain percobaan}

Penelitian tanpa ulangan dan ditanam 1 baris (25 tanaman) per galur dengan jarak tanam $30 \mathrm{~cm} \times 50 \mathrm{~cm}$. Umur semaian pada saat tanam adalah 27 hari setelah semai.

Pembersihan lahan sebelum olah tanah dilakukan dengan menggunakan herbisida. Pengolahan tanah dilakukan dua kali dengan menggunakan traktor pada olah tanah 1 serta cangkul dan tajak (alat tradisional) pada olah tanah 2. Pemupukan Phonska dosis $300 \mathrm{~kg} \mathrm{ha}^{-1}$ diberikan sekaligus pada 4 mst dan Urea $100 \mathrm{~kg}$ $\mathrm{ha}^{-1}$ diberikan dua kali, yaitu $50 \mathrm{~kg} \mathrm{ha}^{-1}$ pada $2 \mathrm{mst}$ dan $50 \mathrm{kgha}^{-1}$ pada $8 \mathrm{mst}$. Pengendalian hama dilakukan setiap minggu sedangkan penyakit setiap dua minggu. Gulma dikendalikan secara manual dan herbisida. Pelabelan tanaman berbunga dilakukan setiap 2 hari dimulai sejak ada tanaman yang bebunga. Panen dilakukan terhadap 
rumpun yang telah $90 \%$ masak penuh, dilakukan 2 hari sekali.

\section{Pengamatan}

Pengamatan dilakukan pada $50 \%(150$ galur) dari 300 galur yang berbunga paling awal, terdiri dari 62 galur asal induk Siam Harli dan 88 galur asal induk Siam Kuatek, masing-masing pada 10 tanaman. Variabel yang diamati adalah umur berbunga (hari setelah semai), umur panen (hari setelah semai), tinggi tanaman $(\mathrm{cm})$, jumlah malai, panjang malai $(\mathrm{cm})$, jumlah gabah isi per malai, jumlah gabah hampa per malai, jumlah gabah, bobot gabah isi per malai, bobot 1000 butir gabah (gram), dan persentase gabah isi (\%).

\section{Analisis data}

Keseragaman dalam galur dianalisis dengan membandingkan ragam mutan terpilih dengan ragam induk masing-masing dihitung dengan rumus sebagai berikut:

$$
\begin{aligned}
& \operatorname{Ragam}\left(\mathrm{V}_{\mathrm{g}}\right)=\sum\left(\mathrm{Y}_{\mathrm{ig}}-\mathrm{Y}_{\mathrm{g}}\right)^{2} \\
& \operatorname{Ragam}\left(\mathrm{V}_{\mathrm{t}}\right)=\sum\left(\mathrm{Y}_{\mathrm{it}}-\overline{\mathrm{Y}}_{\mathrm{t}}\right)^{2}
\end{aligned}
$$

Keterangan :

$\mathrm{V}_{\mathrm{g}}=$ ragam suatu galur (misal galur $\mathrm{A}$ )

$\mathrm{Y}_{\mathrm{ig}}=$ nilai pengamatan pada tanaman ke-i suatu galur

$\overline{\mathrm{Y}}_{\mathrm{g}}=$ nilai rata-rata galur (misal galur $\mathrm{A}$ )

$\mathrm{V}_{\mathrm{t}}=$ ragam induk

$\mathrm{Y}_{\mathrm{it}}=$ nilai pengamatan pada tanaman ke-i suatu induk

$\overline{\mathrm{Y}}_{\mathrm{t}}=$ nilai rata-rata induk

$\mathrm{Uji}$ Kesamaan ragam $=\mathrm{V}_{\mathrm{g}} / \mathrm{V}_{\mathrm{t}}$

Ragam suatu galur tidak lebih besardaripada ragam indukjika $\mathrm{V}_{\mathrm{g}} / \mathrm{V}_{\mathrm{t}}<\mathrm{F}_{0.05}\left(\mathrm{n}_{1-1} ; \mathrm{n}_{2-1}\right)$.

Keragaman antar galur dianalisis dengan membandingkan ragam semua galur terpilih pada induk yang sama dengan rumus sebagai berikut:

$$
\begin{aligned}
& \operatorname{Ragam}\left(\mathrm{V}_{\mathrm{sg}}\right)=\sum\left(\mathrm{Y}_{\mathrm{isg}}-\mathrm{Y}_{\mathrm{sg}}\right)^{2} \\
& \operatorname{Ragam}\left(\mathrm{V}_{\mathrm{t}}\right)=\sum\left(\mathrm{Y}_{\mathrm{it}}-\mathrm{Y}_{\mathrm{t}}\right)^{2}
\end{aligned}
$$

Keterangan :

$\mathrm{V}_{\mathrm{sg}}=$ ragam semua galur yang berasal dari induk yang sama
$\mathrm{Y}_{\text {sig }}=$ rata-rata pengamatan galur ke-i

$\overline{\mathrm{Y}}_{\text {sg }}=$ nilai rata-rata semua galur

$\mathrm{V}_{\mathrm{t}}=$ ragam induk

$\mathrm{Y}_{\mathrm{it}}=$ nilai pengamatan pada tanaman ke-i suatu induk

$\overline{\mathrm{Y}}_{\mathrm{t}}=$ nilai rata-rata induk

Uji Kesamaan ragam $=\mathrm{V}_{\mathrm{sg}} / \mathrm{V}_{\mathrm{t}}$

Ragam semua galur tidak lebih besar daripada ragam induk jika $\mathrm{V}_{\mathrm{sg}} / \mathrm{V}_{\mathrm{t}}<\mathrm{F}_{0.05}\left(\mathrm{n}_{1-1} ; \mathrm{n}_{2-1}\right)$.

\section{HASIL DAN PEMBAHASAN}

Rekapitulasi hasil pengujian kesamaan ragam antara masing-masing galur mutan dengan induk Siam Harli dapat dilihat pada Tabel 1 dan galur mutan dengan induk Siam Kuatek dapat dilihat pada Tabel 2. Sebagian besar karakter pada 62 galur mutan M5 asal induk Siam Harli mempunyai nilai varians yang tidak berbeda nyata dengan induknya (> $85 \%$ ), atau dengan kata lain sudah seragam dalam galur. Karakter yang sudah seragam pada semua galur mutan M5 adalah umur berbunga, tinggi tanaman, umur panen, jumlah gabah isi, jumlah gabah hampa, bobot gabah isi, dan jumlah gabah total.Terdapat 4 karakter agronomi yang memiliki varians lebih besar daripada induknya, yaitu karakter jumlah malai sebanyak 1 galur $(1,61 \%)$, panjang malai 2 galur $(3,23 \%)$, bobot 1000 butir 9 galur $(14,52 \%)$, dan persentase gabah isi 1 galur $(1,61 \%)$.

Hasil yang serupa juga terdapat pada galur mutan M5 induk Siam Harli. Sebagian besar karakter pada 88 galur mutan M5 asal induk Siam Kuatek juga mempunyai nilai varians yang tidak berbeda nyata dengan induknya ( $>79 \%$ ), atau dengan kata lain sudah seragam dalam galur (Tabel 2). Karakter yang sudah seragam pada semua galur mutan M5 adalah umur panen, jumlah malai, jumlah gabah isi, jumlah gabah hampa, dan jumlah gabah, sedangkan 6 karakter agronomi masih belum seragam, yaitu umur berbunga menunjukkan bahwa 18 galur mutan $(20,45 \%)$ nilai variansnya lebih besar dari induknya, 1 galur mutan pada panjang malai $(1,14$ $\%), 10$ galur mutan pada bobot gabah isi $(11,36$ $\%), 3$ galur mutan pada bobot 1000 butir $(3,41 \%)$, dan 1 galur mutan pada persentase gabah isi $(1,14 \%)$. 
Tabel 1. Rekapitulasi jumlah galur mutan M5 yang mempunyai varians tidak berbeda nyata dengan induknya (Siam Harli)

\begin{tabular}{lrrrrr}
\hline \multicolumn{1}{c}{ Variabel } & $\mathrm{V}_{\mathrm{g}}>\mathrm{V}_{\mathrm{t}}$ & $\mathrm{V}_{\mathrm{g}} \mathrm{ns} \mathrm{V}_{\mathrm{t}}$ & \multicolumn{1}{c}{$\mathrm{TJG}$} & $\% \mathrm{~V}_{\mathrm{g}}>\mathrm{V}_{\mathrm{t}}$ & $\% \mathrm{~V}_{\mathrm{g}} \mathrm{ns} \mathrm{V}_{\mathrm{t}}$ \\
\hline Umur berbunga (hss) & 0 & 62 & 62 & 0.00 & 100.00 \\
Tinggi tanaman (cm) & 0 & 62 & 62 & 0.00 & 100.00 \\
Umur panen (hss) & 0 & 62 & 62 & 0.00 & 100.00 \\
Jumlah malai (helai) & 1 & 61 & 62 & 1.61 & 98.39 \\
Panjang malai (cm) & 2 & 60 & 62 & 3.23 & 96.77 \\
Jumlah gabah isi (butir) & 0 & 62 & 62 & 0.00 & 100.00 \\
Jumlah gabah hampa (butir) & 0 & 62 & 62 & 0.00 & 100.00 \\
Bobot gabah isi (g) & 0 & 62 & 62 & 0.00 & 100.00 \\
Bobot 1000 butir (g) & 9 & 53 & 62 & 14.52 & 85.48 \\
Jumlah gabah (butir) & 0 & 62 & 62 & 0.00 & 100.00 \\
Persentase gabah isi (\%) & 1 & 61 & 62 & 1.61 & 98.39 \\
\hline
\end{tabular}

Keterangan: $\mathrm{V}_{\mathrm{g}}>\mathrm{V}_{\mathrm{t}}=$ Jumlahgalur yang ragamnya $>$ ragam induk; $\mathrm{V}_{\mathrm{g}} \mathrm{ns} \mathrm{V}_{\mathrm{t}}=$ Jumlah galur yang ragamnya tidak berbeda dengan ragam induk; \% Vg $>\mathrm{V}_{\mathrm{t}}=$ persentase galur yang ragamnya $>$ ragam induk; $\% \mathrm{~V}_{\mathrm{g}} \mathrm{ns} \mathrm{V}_{\mathrm{t}}=$ persentasegalur yang ragamnya tidak berbeda dengan ragam induk

Jika galur yang memiliki karakter yang diinginkan belum seragam, maka perlu dilakukan penggaluran kembali agar diperoleh keseragam pada galur tersebut. Karakter yang sudah seragam pada semua galur M5, baik asal induk Siam harli maupun Siam Kuatek adalah umur panen, jumlah gabah isi, dan jumlah gabah hampa.

Beberapa peneliti melaporkan bahwa terdapat galur-galur yang seragam dan galur-galur yang belum seragam pada sejumlah galur yang diuji. Arjana [11], melaporkan keseragaman karakter tinggi tanaman, panjang malai, bobot 1000 butir gabah, bobot gabah per rumpun, jumlah gabah total per malai, dan jumlah anakan pada 16 galur $(80 \%)$ dari 20 genotipe padi beras merah hasil empat kali seleksi silang balik. Ketidak seragaman 4 galur lainnya ditunjukkan dari panjang malai, bobot gabah per rumpun, total gabah per malai dan total anakan per rumpun dan atau tinggi tanaman. Abdullah dkk. [12],

Tabel 2. Rekapitulasi jumlah galur mutan M5 yang mempunyai varians tidak berbeda nyata dengan induknya (Siam Kuatek)

\begin{tabular}{lrrrrr}
\hline \multicolumn{1}{c}{ Variabel } & $\mathrm{V}_{\mathrm{g}}>\mathrm{V}_{\mathrm{t}}$ & $\mathrm{V}_{\mathrm{g}} \mathrm{ns} \mathrm{V}_{\mathrm{t}}$ & \multicolumn{1}{c}{$\mathrm{TJG}$} & $\% \mathrm{~V}_{\mathrm{g}}>\mathrm{V}_{\mathrm{t}}$ & $\% \mathrm{~V}_{\mathrm{g}} \mathrm{ns} \mathrm{V}_{\mathrm{t}}$ \\
\hline Umur berbunga (hss) & 18 & 70 & 88 & 20.45 & 79.55 \\
Tinggi tanaman (cm) & 1 & 87 & 88 & 1.14 & 98.86 \\
Umur panen (hss) & 0 & 88 & 88 & 0.00 & 100.00 \\
Jumlah malai (helai) & 0 & 88 & 88 & 0.00 & 100.00 \\
Panjang malai (cm) & 1 & 87 & 88 & 1.14 & 98.86 \\
Jumlah gabah isi (butir) & 0 & 88 & 88 & 0.00 & 100.00 \\
Jumlah gabah hampa (butir) & 0 & 88 & 88 & 0.00 & 100.00 \\
Bobot gabah isi (g) & 10 & 78 & 88 & 11.36 & 88.64 \\
Bobot 1000 butir (g) & 3 & 85 & 88 & 3.41 & 96.59 \\
Jumlah gabah (butir) & 0 & 88 & 88 & 0.00 & 100.00 \\
Persentase gabah isi (\%) & 1 & 87 & 88 & 1.14 & 98.86 \\
\hline
\end{tabular}

Keterangan: $\mathrm{V}_{\mathrm{g}}>\mathrm{V}_{\mathrm{t}}=$ Jumlah galur yang ragamnya $>$ ragam induk; $\mathrm{V}_{\mathrm{g}} \mathrm{ns} \mathrm{V}_{\mathrm{t}}=$ Jumlah galur yang ragamnya tidak berbeda dengan ragam induk; $\% \mathrm{Vg}>\mathrm{V}_{\mathrm{t}}=$ persentase galur yang ragamnya $>$ ragam induk; $\% \mathrm{~V}_{\mathrm{g}} \mathrm{ns} \mathrm{V}_{\mathrm{t}}=$ persentase galur yang ragamnya tidak berbeda dengan ragam induk 
melaporkan bahwa 2885 galur padi tipe baru (PTB) dari 2915 galur belum seragam, kemudian 417 galur PTB yang belum seragam digalurkan lagi, karena mempunyai sifat yang diharapkan.

Rekapitulasi hasil pengujian keragaman antara semua galur mutan yang berasal dari induk yang sama dengan induk masing-masing dapat dilihat pada Tabel 3. Keragaman yang besar dalam populasi tanaman akan memberikan kesempatan yang besar untuk memperoleh genotipe dengan sifat yang diinginkan [10]. padi, yaitu pada karakter tinggi tanaman, jumlah anakan produktif, jumlah malai, lama stadia vegetatif, jumlah gabah hampa per malai, persentase gabah hampa per malai, bobot 1000 butir produksi per plot dan diameter batang.

Pemuliaan mutasi pada tanaman padi dimaksudkan sebagai salah satu metode untuk menciptakan keragaman genetik yang luas, sehingga dimungkinkan tersedianya materi seleksi untuk memilih mutan-mutan dengan sifat-sifat yang dikendaki [14]. Tabel 4 menunjukkan tidak

Tabel 3. Hasil uji keragaman antara semua galur mutan dengan masing-masing induknya

\begin{tabular}{|c|c|c|c|c|c|c|}
\hline Variabel Pengamatan & $\begin{array}{l}\text { Varians } \\
\text { M5 asal } \\
\text { S. Harli }\end{array}$ & $\begin{array}{l}\text { Varians } \\
\text { S. Harli }\end{array}$ & $\begin{array}{c}\text { Rasio } \\
\text { varians } \\
\text { M5 \& S. } \\
\text { Harli }\end{array}$ & $\begin{array}{c}\text { Varians } \\
\text { M5 asal } \\
\text { S. Kua- } \\
\text { tek }\end{array}$ & $\begin{array}{l}\text { Varians } \\
\text { S. Kua- } \\
\text { tek }\end{array}$ & $\begin{array}{c}\text { Rasio } \\
\text { varians } \\
\text { M5 \& S. } \\
\text { Kuatek }\end{array}$ \\
\hline Umur berbunga (hss) & 1,13 & 3,56 & 0,32 & 0,91 & 1,07 & 0,85 \\
\hline Tinggi tanaman $(\mathrm{cm})$ & 7,31 & 42,65 & 0,17 & 17,26 & 36,13 & 0,48 \\
\hline Umur panen (hss) & 1,14 & 8,71 & 0,13 & 0,91 & 2,40 & 0,38 \\
\hline Jumlah malai (helai) & 27,95 & 62,04 & 0,45 & 22,26 & 64,23 & 0,35 \\
\hline Panjang malai (cm) & 0,58 & 1,62 & 0,36 & 0,55 & 1,93 & 0,28 \\
\hline Jumlah gabah isi (butir) & 151,21 & 695,57 & 0,22 & 84,39 & 470,90 & 0,18 \\
\hline Jumlah gabah hampa (butir) & 7,12 & 108,06 & 0,07 & 10,26 & 280,28 & 0,04 \\
\hline Bobot gabah isi (g) & 0,10 & 0,26 & 0,38 & 0,05 & 0,09 & 0,56 \\
\hline Bobot 1000 butir (g) & 0,36 & 0,54 & 0,67 & 0,54 & 3,38 & 0,16 \\
\hline Jumlah gabah (butir) & 171,65 & 805,29 & 0,21 & 100,29 & 979,51 & 0,10 \\
\hline Persentase gabah isi (\%) & 5,47 & 40,16 & 0,14 & 0,91 & 1,07 & 0,85 \\
\hline
\end{tabular}

Keterangan : Varians galur mutan M5> varians induk jika rasio antara keduanya $>$ dari 3,18

Rekapitulasi rata-rata, maksimum, dan minimum dapat dilihat pada Tabel 4. Hasil uji keragaman antara semua galur mutan dengan induknya menunjukkan bahwa nilai varians semua rata-rata galur mutan tidak lebih besar daripada nilai masing-masing induknya.Namun demikian, jika dilihat dari perbandingan nilai karakter agronomi yang diamati dari semua galur mutan dengan masing-masing induknya (Tabel 4) nampaknya masih terdapat kemungkinan seleksi ke arah karakter yang lebih baik, karena nilai minimum atau maksimum galur mutan lebih baik daripada induknya. Dengan demikian, dapat dinyatakan bahwa perlakuan radiasi sinar gamma pada varietas Siam Harli dan Siam Kuatek dapat membawa perubahan yang positif terhadap beberapa karakter agronomi. Hal yang senada dilaporkan oleh Sitorus [13], bahwa radiasi berpengaruh nyata pada generasi M5 galur mutan ada satupun galur mutan yang mempunyai karakter umur berbunga, tinggi tanaman, dan umur panen, sama atau lebih panjang dari induknya yang merupakan varietas lokal.

Rerata umur berbunga, tinggi tanaman, dan umur panen dari galur-galur mutan M5 asal induk Siam Harli jauh lebih rendah daripada induknya (Tabel 4). Penurunan umur berbunga adalah $35,01 \%$, yaitu dari 130 hari setelah semai menjadi 84,49 hari setelah semai, sedangkan umur panen adalah 29, $92 \%$, yaitu dari 163,40 hari setelah semai menjadi 114,51 hari setelah semai. Hal yang sama nampak pada galur mutan M5 asal induk Siam Kuatek. Penurunan umur berbunga adalah $37,93 \%$, yaitu dari 137,2 hari setelah semai menjadi 85,16 hari setelah semai sedangkan penurunan umur panen adalah $32,97 \%$, yaitu dari 171,80 hari setelah semai menjadi 115,16 hari setelah semai. Pemendekan umur tanaman padi 
Tabel 4. Rekapitulasi nilai rata-rata, maksimum, dan minimum galur mutan M5 asal Induk Siam Harli dan Siam Kuatek

\begin{tabular}{|c|c|c|c|c|c|c|c|c|}
\hline \multirow{2}{*}{$\begin{array}{l}\text { Variabel } \\
\text { Peng- } \\
\text { amatan }\end{array}$} & \multicolumn{3}{|c|}{$\begin{array}{l}\text { Galur-galur Mutan } \\
\text { M5 Siam Harli }\end{array}$} & \multirow{2}{*}{$\begin{array}{c}\text { Rerata } \\
\text { Siam } \\
\text { Harli }\end{array}$} & \multicolumn{3}{|c|}{$\begin{array}{l}\text { Galur-galur Mutan } \\
\text { M5 Siam Kuatek }\end{array}$} & \multirow{2}{*}{$\begin{array}{l}\text { Rerata } \\
\text { Siam } \\
\text { Kuatek }\end{array}$} \\
\hline & Rerata & Maks & Min & & Rerata & Maks & Min & \\
\hline UB & 84,49 & 86,20 & 82,20 & 130,00 & 85,16 & 86,20 & 80,80 & 137,20 \\
\hline $\mathrm{T}$ & 81,64 & 87,70 & 77,76 & 123,40 & 84,07 & 76,90 & 96,68 & 116,35 \\
\hline UP & 114,51 & 116,20 & 112,20 & 163,40 & 115,16 & 116,20 & 110,80 & 171,80 \\
\hline $\mathrm{JM}$ & 33,27 & 44,40 & 20,00 & 25,40 & 35,17 & 46,80 & 19,60 & 21,70 \\
\hline PM & 23,99 & 26,27 & 22,43 & 27,83 & 24,39 & 27,53 & 22,38 & 25,56 \\
\hline GI & 97,50 & 128,70 & 79,90 & 131,70 & 104,14 & 133,50 & 81,40 & 102,70 \\
\hline $\mathrm{GH}$ & 9,44 & 17,30 & 5,00 & 21,50 & 10,97 & 20,30 & 5,20 & 44,50 \\
\hline BGI & 2,31 & 3,13 & 1,68 & 2,58 & 2,45 & 3,19 & 1,83 & 1,76 \\
\hline B1000 & 23,70 & 25,03 & 22,21 & 19,59 & 23,59 & 25,93 & 21,80 & 17,29 \\
\hline JG & 106,94 & 142,20 & 81,40 & 153,20 & 115,01 & 148,70 & 91,00 & 147,20 \\
\hline$\%$ GI & 91,12 & 94,75 & 84,46 & 85,93 & 90,41 & 94,67 & 81,36 & 69,97 \\
\hline
\end{tabular}

Keterangan : UB $=$ Umur berbunga (hss); $\mathrm{T}=$ Tinggi tanaman $(\mathrm{cm})$; UP $=$ Umur panen (hss); JM = Jumlah malai (helai); $\mathrm{PM}=$ Panjang malai $(\mathrm{cm})$; JGI = Jumlah gabah isi (butir); JGH = Jumlah gabah hampa (butir) BGI =Bobot gabah isi (g); B1000 = Bobot 1000 butir (g); $\mathrm{JG}=\mathrm{Jumlah}$ gabah (butir); PI = Persentase gabah isi (\%)

hingga 2 bulan juga ditemukan pada mutan Pandan Puteri asal induk varietas Pandan Wangi [6].

Varietas padi lokal pada umumnya berumur panjang. BPTP Sumbar 2012, melaporkan bahwa kisaran umur berbunga koleksi plasma nutfah varietas padi lokal Sumatera Barat sangat lebar, yaitu 87-130 hari, dengan umur masak panen 119 - 162 hari (genjah - dalam). Kisaran waktu panen mutan Kultivar Sijunjung adalah $89-118$ HSS (tanaman kontrol 134 hari setelah semai/HSS), sehingga percepatan waktu panen mutan kultivar Sijunjung adalah 16-45 hari, sedangkan kisaran waktu panen mutan padi Kultivar Kuriak Kusuik adalah $103-118$ HSS (tanaman induk 155 HSS), sehingga percepatan waktu panen mutan kultivar Kuriak Kusuik adalah 37 -52 hari [15].

Perpendekan umur tanaman padi dengan teknik mutasi induksi juga diperoleh pada pemuliaan padi di Myanmar [16]. Galur mutan yang diperoleh, yaitu SPM2 dan SPM 39 mempunyai umur panen 122 dan 119 hari setelah tanam (HST) dibandingkan induknya yang mempunyai umur panen 150 HST [17]. Pada populasi mutan Ocimum sanctum Linn. mempunyai umur berbunga 19-29 hari setelah perkecambahan (hsp), sedangkan induknya 40-50 hsp [18]. HAKIM [19], melaporkan terjadinya perubahan umur panen pada galur mutan M4 kacang hijau dibandingkan dengan varietas induknya (varietas Betet).

Arah pemuliaan tanaman yang utama dalam penelitian ini adalah memendekkan umur tanaman, karena dengan umur yang panjang pada varietas padi lokal dapat menyebabkan terjadinya gagal panen atau pengurangan hasil akibat kebanjiran pada awal tanam dan kekeringan pada fase pengisian biji dan pematangan. Di sisi lain varietas padi yang berumur panjang tidak selalu menghasilkan produksi gabah yang tinggi. Dengan pemendekan umur tanaman, diharapkan pola tanam padi lokal yang satu kali dalam setahun terutama dilahan pasang surut di Kalimantan Selatan [3] dan di rawa Pulau Rimau, Kabupaten Musi Banyuasin, Sumatera Selatan [20] dapat dijadikan 2 kali setahun. Selain itu dengan perbaikan karakter tersebut juga dapat mengantisipasi perubahan iklim yang turut mengganggu produksi [21], karena umur tanaman padi lokal sejak semai sampai panen 6-7 bulan $[3,20]$.

Berdasarkan nilai rata-rata (Tabel 4), terjadi penurunan karakter tinggi tanaman pada galur mutan M5, baik dari induk Siam harli maupun Siam Kuatek, yaitu berturut-turut 33, $84 \%$ dan $27,74 \%$. Dengan demikian semua galur tergolong pendek $(<110 \mathrm{~cm})$ menurut Soedjono [22]. Wahdah dan Zulhidiani [23], melaporkan bahwa 
sinar gamma dapat menyebabkan tanaman padi menjadi lebih tinggi atau sebaliknya menjadi lebih pendek, tetapi karena seleksi dilakukan ke arah tanaman pendek, maka tidak ada galur mutan M5 yang tingginya melebihi induknya. Hal sama juga ditemukan pada tanaman padi $[19,24)]$ dan kacang hijau [25].

Tanaman yang pendek dapat disebabkan oleh ketidaknormalan fungsi giberilin [26]. Induksi mutasi di Malaysia [17] dan Myanmar [16] juga menghasilkan padi mutan yang lebih pendek daripada induknya. Di samping itu induksi mutasi di Malaysia juga menghasilkan padi mutan yang berproduksi lebih tinggi daripada induknya.

Adanya rentang nilai maksimum dan minimum terutama pada karakter selain umur berbunga, umur panen, dan tinggi tanaman memberikan peluang untukmelakukan seleksi galur yang memiliki karakter lebih baik dari induknya. Rentang yang cukup besar terdapat pada karakter jumlah malai, panjang malai, jumlah gabah isi, jumlah gabah hampa, bobot gabah isi, jumlah gabah, dan persentase gabah isi.

Nilai maksimum rerata galur mutan M5 asal induk Siam Harli dan Siam Kuatek yang lebih baik dibandingkan induknya adalah pada karakter jumlah malai, jumlah gabah hampa, bobot gabah isi per malai, dan jumlah gabah, sedangkan nilai minimum galur mutan M5 yang lebih baik daripada induknya adalah umur berbunga, tinggi tanaman, umur panen.

Tidak ada satupun galur mutan M5 yang mempunyai karakter ukuran gabah (dipresentasikan oleh bobot 1000 butir gabah) lebih kecil dari induknya. Akan tetapi dibandingkan dengan varietas unggul inbrida padi rawa, terdapat galur-galur bobot 1000 butirnya lebih kecil daripada Inpara3, Inpara 5, dan Inpara 1.

Namun demikian, kerampingan tidak selalu berkaitan dengan bobot butiran gabah, tetapi oleh lebar dan panjang gabah sebagai tolok ukur kerampingan. Hal positif dari ukuran gabah yang lebih besar adalah sumbangannya terhadap hasil tanaman. Mugiono dkk. [9], melaporkan bahwa pemuliaan mutasi padi juga menghasilkan perubahan karakter pada berat 1000 butir, jumlah gabah isi, dan jumlah gabah hampa permalai.

Adanya rentang yang cukup besar pada beberapa karakter mengindikasikan adanya variasi dibandingkan dengan induknya. Menurut Ishak [27], terdapat variasi jumlah gabah, bobot 1000 butir, dan hasil per petak dibandingkan induknya
Situgintung. Mahyani [8], menyatakan bahwa tujuh galur mutan padi yang diuji menunjukkan semuanya nyata lebih pendek dari induknya, mempunyai butir gabah yang lebih besar serta produksi yang sedikit lebih tinggi dibandingkan dengan induknya.

\section{KESIMPULAN}

Dari hasil penelitian ini dapat diambil beberapa kesimpulan, yaitu:

1. Lebih dari 85 galur mutan M5 asal induk Siam Harli dan $>79 \%$ asal induk Siam Kuatek sudah seragam.

2. Tidak ada keragaman antar galur mutan M5, tetapi sebagian galur induk asal Siam Harli maupun Siam Kuatek lebih baik daripada induknya, sehingga terbuka peluang untuk memilih galur-galur yang lebih baik daripada induknya.

\section{UCAPAN TERIMAKASIH}

Terimakasih disampaikan kepada : PAIRBATAN yang membantu meradiasi padi varietas lokal dengan sinar gamma (tahun 2010) yang menjadi materi penelitian dan Islamic Development Bank, Direktorat Penelitian dan Pengabdian kepada Masyarakat Dirjen Dikti, dan Lembaga Penelitian Unlam atas dana yang diberikan melalui Penelitian Unggulan Perguruan Tinggi tahun 2014.

\section{DAFTAR PUSTAKA}

1. Djaenudin, D. Perkembangan penelitian sumber daya lahan dan kontribusinya untuk mengatasi kebutuhan lahan pertanian di Indonesia, J. Litbang Pertanian, 27 (4), 137-145, 2008.

2. Sudana, W. Potensi dan prospek lahan rawa sebagai sumber produksi pertanian, Analisis Kebijakan Pertanian, 3 (2), 141$151,2005$.

3. Wahdah, R., B.F. Langai, Preferensi Petani Terhadap Varietas Padi Lokal di Area Pasang Surut Kabupaten Tanah Laut dan 
Kabupaten Barito Kuala, Media Sains, 2 (1), 114-120, 2010.

4. BPSBTPH Kalimantan Selatan. Laporan Tahunan 2012, Banjarbaru: Balai Pengawasan dan Sertifikasi Benih Tanaman Pangan dan Hortikultura Wilayah XI, 2013.

5. Wahdah, R., B.F. Langai, Observasi varietas padi lokal di lahan pasang surut Kalimantan Selatan, Agroscientiae, 16 (3), 177-184, 2009.

6. Ismachin, M., Sobrizal. A significant contribution of mutation techniques to rice breeding in Indonesia. Plant Mutation Reports, 1 (1), 18-21, 2006.

7. Widiastuti, A., Sobir, M.R. Suhartanto, Analisis keragaman genetik manggis (Garcinia mangostana) diiradiasi dengan sinar gamma berdasarkan penanda ISSR, Bioteknologi, 10 (1), 1522, 2013.

8. Mahyani, I., Studi Sifat-sifat mutan padi gogo, Pusat Aplikasi Isotop dan Radiasi, Batan. p.351-363 (1990). http://digilib.batan.go.id/e prosiding/, Diakses tanggal 27 Oktober 2014.

9. Mugiono, L. Harsanti, A.K. Dewi, Perbaikan padi varietas Cisantana dengan mutasi induksi. Jurnal Ilmiah Aplikasi Isotop dan Radiasi, 5 (2), 194-210, 2009.

10. Sasmita, P., Evaluation of uniformity, variability, and stability of agronomic traits of doubled haploid rice lines resulting from anther culture, Bioscience, 2 (2), 67-72, 2009.

11. Arjana, I.G.P.M., Uji keseragaman, heritabilitas dan kemajuan genetik galur padi beras merah hasil seleksi silang balik di lingkungan gogo, PS Agroekoteknologi Faperta Unram, 2012, http://www.fp.unram.ac.id.

12. Abdullah, B., B. Suwarna, B. Kustianto, H. Siregar, Pembentukan galur padi sawah tipe baru, h. 199-207, Prosiding Seminar
Hasil Penelitian Rintisan dan Bioteknologi Tanaman, 2003.

13. Sitorus, B.F., Seleksi tanaman mutan galur mutan M5 untuk menghasilkan genotipe padi (Oryza sativa L.) tahan rebah dan produksi tinggi, Skripsi, Departemen Budidaya Tanaman Fakultas Pertanian Universitas Sumatera Utara, Medan, 2011.

14. Riwidiharso, E., A.H. Susanto, Pengaruh radiasi sinar gama terhadap perkecambahan padi ketan, Biosfera 3, 13-17, 1996.

15. Suliansyah, I., Perbaikan padi lokal Sumatera Barat melalui pemuliaan mutasi, Seminar Nasional : Reformasi Pertanian Terintegrasi Menuju Kedaulatan Pangan. Fakultas Pertanian Universitas Trunojoyo, 20 Oktober 2011.

16. New, K.T., Rice mutation breeding for varietal improvement in Myanmar, Plant Mutation Reports, 1 (1), 34-36, 2006.

17. Mohamad, O., B.M. Nazir, I. Alia., S. Azlan, H.A. Rahim2, M.Z. Abdullah, O. Othman, K. Hadzim, A. Saad, H. Habibuddin, F. Golam, Development of improved rice varieties through the use of induced mutations in Malaysia, Plant Mutation Reports, 1 (1), 27-33, 2006.

18. Nasare, P.N., A.D. Choudhary, Early flowering and high yielding mutants In Ocimum sanctum Linn, Indian Streams Research Journal 1 (III), 202-204, 2011.

19. Hakim, L., Analisis korelasi dan regresi pada populasi galur mutan kacang hijau dan implikasinya dalam seleksi, J. Penelitian Pertanian Tanaman Pangan, 26 (2), 114-119, 2007.

20. Wirosoedarmo, R., U. Apriadi, Studi Perencanaan pola tanam dan pola operasi pintu air jaringan reklamasi rawa Pulau Rimau di Kabupaten Musi Banyuasin Sumatera Selatan, Jurnal Teknologi Pertanian, 3 (1), 56-66, 2008. 
21. Suciantini, Impron, R. Boer, Penilaian resiko iklim pada sistem pertanian ekologi lahan rawa pasang surut (Studi Kasus di Desa Telang I, Desa Telang II, dan Delta Air Saleh, Banyu Asin Sumatera Selatan). J. Agromet, 22 (2), 118-131, 2008.

22. Soedjono, S., Aplikasi mutasi induksi dan variasi somaklonal dalam pemuliaan tanaman, Jurnal Litbang Pertanian, 22 (2), 70-78, 2003.

23. Wahdah, R., R. Zulhidiani, Evaluasi M3 lima varietas padi lokal Kalimantan Selatan yang diiradiasi dengan tiga dosis sinar gamma dalam upaya menghasilkan varietas berumur sedang, Laporan Penelitian, Fakultas Pertanian UnlamKonsorsium Padi Nasional, Banjarbaru, 2012.
24. Sobrizal, Pemuliaan mutasi dalam peningkatan manfaat galur-galur terseleksi asal persilangan antar subspesies padi, Jurnal Ilmiah Aplikasi Isotop dan Radiasi, 4 (1), 1-11, 2008.

25. Mohamad, O., O. Ramli, J. Mahmud, A glutinous and short-stature mutant of the rice variety Manik, Mardi Res. J., 22 (1), 23-28, 1994.

26. Sasaki, A., M. Ashikari, M. Ueguchi-Tanaka, H. Itoh, A. Nishimura, D. Swapan, K. Ishiyama, T. Saito, M. Kobayashi, G. S. Khush H. Kitano, M. Matsuoka, A mutant gibberellin-synthesis gene in rice. Nature, 416, 701, 2002.

27. Ishak, Sifat Agronomis, heritabilitas dan interaksi $\mathrm{g} \mathrm{x}$ e galur mutan padi gogo (Oryza sativa L.), J. Agron. Indonesia, 40 (2), 105-111, 2012. 
Jurnal Ilmiah Aplikasi Isotop dan Radiasi

A Scientific Journal for The Applications of Isotopes and Radiation

ISSN 1907-0322 Vol. 12 No. 2 Desember 2016 